\title{
Empirical Analysis of Regional Potential Trade: Case of Ecowas and SADC
}

\author{
Aissata Diallo ${ }^{1, *}$, Siba Kolin Koivogui ${ }^{2}$, Hady. B. Bah ${ }^{3}$ \\ ${ }^{1}$ School of Economics and Management Beijing Forestry University, Beijing Haidian, P.R China \\ ${ }^{2}$ Higher Agricultural and Veterinary Institute and Veterinary of Faranah, Republic of Guinea Faranah \\ ${ }^{3}$ School of tea and food science Anhui Agricultural University PO box 2300036, 130Changjiangxilu, Anhui China \\ *Corresponding author: aicha2diallo@gmail.com
}

\begin{abstract}
This paper aims to find export, import and total trade determinants potential of Africa by using panel data method in analysis process from gravity model approach for 35years observations from 1980 to 2015. The previous results on trade potential based in panel data set estimated with the fixed /random model. It is methodology used to evaluate Africa exports potential in a period characterized by strong restrictions on trade, based on the estimates generated by a gravity model for Southern and western African Development Community member countries and their exports to China and the rest of the world. The study purpose is to compare Africa potential trade with partners include China, random effects, fixed effects models are used to estimate data analysis with Hausman test for testing equation and prediction alpha for all variables has been used. Data analysis results show that the potential trade was highly significant at $1 \%$ level $\left(3.80^{* * *}\right)$ between China and ECOWAS countries and significant at $5 \%$ level in SADC countries (3.86**). In terms of partnership, the potential trade was highly significant from EU to ECOWAS/SADC with $5 \%$ level compared to JAPAN and USA. In terms of international trade potential, from Figure 7, the prediction values have been standard from 1980 to 1990, due in fact of factory level in these countries judged very low at that period and stated increasing from 2000 to 2020. It should be conclude that From 2000 to 2018.
\end{abstract}

Keywords: regional integration, trade potential, empirical, Africa, Ecowas, SADC

Cite This Article: Aissata Diallo, Siba Kolin Koivogui, and Hady. B. Bah, "Empirical Analysis of Regional Potential Trade: Case of Ecowas and SADC.” Journal of Finance and Economics, vol. 6, no. 1 (2018): 1-13. doi: 10.12691/jfe-6-1-1.

\section{Introduction}

Most part developed countries, economic growth and economy stability is due the high level of international and intra-regional trade motivated by good economic substructure. According to [1], Regional integration trade is the process which two or more states give agreements to cooperate and work closely together to achieve peace, stability and wealth. According to [2], Poor infrastructure and institutions contribute to high trade cost within sub Saharan countries. High trade cost has a negative impact on a country economic showing in several ways Moreover, data and evidence suggest that African countries have some of the highest trade costs in the world. whereas trade is an important operator of growth and substructure is a necessity for trade, substructure development has a key role to play in economic development. Transport network, transmission technology and energy are the considerable barrier to most developing countries trade.

Economic change, specifically based on trade, industrial improve and afterwards the manufacture of products to sell abroad, have increased China's trade relationships with developed and developing countries.
Empirical evidence's data prove that some African countries have the highest trade costs in the world.

The hypotheses prove that trade potential is equal to the trade adjusted or expected, using the coefficients of the model of gravity, that when the relation between the trade observed and expected is greater than one, that is to say that it can be extend in the future, in case it is low have increased trade flow under conditions that the country improves some of its characteristics. [3] Scholars have included the simple projection approach using in regression analysis, transforming countries under the consideration so [4,5] the residual of the estimation was considered as the difference between potential and actual bilateral trade relation.

Investigate thoroughly the impact on trade performance, not only trade policy reforms that is a relevant measure but also of wider regulatory and economic reform. Trade performance is not only affected by policies that limit or promote trade exchange across national borders; it is also affected by policies, institutions and regulations that facilitate or inhibit trade, investment, and promote openness throughout the economy. Based on some methodologies, potential trade is often estimate using gravity model. According to [6], distinguish between natural or fundamental determinants such as geography, 
size and language, and those that are human or political variables that could affect such as trade agreements, customs unions and import restrictions. This means that the estimation of potential trade requires a procedure that represents the upper limits of the data and not the centered values of the data set Drawing on the procedures developed for estimating stochastic frontier production functions, the objective of this paper is to model and estimating export potential of a country with respect to its trade partner using the gravity model.

However, [7] argue that trade between developing countries has considerable potential to expands, which is an important foundation to establish economic cooperation between them based on the potential of mutually beneficial trade and investment.

The Regional integration is strategy for Africa to accelerate the transformation of small economies fragment, expand their markets on continental economic space to the benefit of production and maximizing the prosperity of their nations, improving market competitivity in global trade to acquire technology and investments access. During the forum of African Union 2000, African leaders therefore see regional integration as an important step towards broad-based development and the establishment of a regional economic communities in accordance with the Treaty establishing in 1991 and the Constitutive Act.

Commerce has involved, hugely to the development of industrialized economies and can be forwarded to Even for the economies of less developed countries, in particular in the case of African economies within WTO 2007. Emergence of China and India as economic take part to the poverty alleviation in the world. while in Africa, has persisted generally in the substance, world trade statistics Indicated that its share of this trade has decreased from $6 \%$, there is nearly $2 \%$ in 2007 , or even less than $1 \%$ if South Africa is Not considered this tendency reflects the growing marginalization Continent in the field of world trade. Besides, most regions are interested to improve their potential resources and economies liberalization having benefits of trade globalization through bilateral or multilateral process. African continents also need same with countries or regions and may know its full potential with countries partners in order on involvements procedure. This paper examines the trade potential of
Africa regional community (RECs), SADC, Ecowas, at GDP of exports of products by using the trade gravity model. The figure below can show African 's Potential Merchandise trade in a various product.

This table shows the intra- and extra-trade of Africa patterns groups by product. It presents their respective exports and imports within the group, with the geographical region to which they belong and the world, in millions of dollars and percentages. Note that oil is included in total exports here. While the shares of each non-oil export sector would increase if oil exports were not taken into accounting the total, the ranking of sectors would not change.

It is further identifying the top African export products to each of the selected regions. For each region, listed in Table 3, the top five export products according to their export value and report their annual growth rate over the past 15 years along with their current market share. In addition, it is listed fast-growing products that have not yet reached high export levels.

Mineral products dominate African exports to all regions. Base metals also always rank among the top five products. Their market share outside Africa are, however, still very small. Exports to traditional markets in Europe consist to a significant part also of raw and processed food and beverages. In terms of growth rates, two sectors are worth noting: starting from very low levels, transport equipment has experienced high growth rates to other OECD and Row markets. As noted earlier, these exports are dominated by SACU. Footwear, headgear, etc. is demonstrating a strong increase in sales to Asia-Pacific, Latin American and Rest-OECD markets. The comparative advantage (RCA) indices for trade help identify the high or low potential trade between trade group in a particular product category the comparative between country jth for the ith product can be write like:

$$
R C A i j=\left(\frac{x i j}{x j i}\right)\left(\frac{\sum x i j}{\sum x j i}\right)
$$

Where: commodities $\mathrm{i}=\{1,2,3, \mathrm{n}$.$\} , ij equal to \mathrm{x}$ exports of the ij-jth product from country $j$,

$\sum \mathrm{Xij}=$ total exports from country $\mathrm{j}, \mathrm{Xij}=$ exports of the $\mathrm{i}-$ jit product from the world,

$\sum \mathrm{Xij}=$ total exports from the world.

Table 1. Composition of African's Merchandise: Intra-trade and extra-trade of country groups by product, annual, 1995-15

\begin{tabular}{|c|c|c|c|c|c|}
\hline \multirow[t]{2}{*}{ African potential domestic products } & \multirow{2}{*}{$\begin{array}{l}\text { Exports in us } \\
\text { billions } 2015\end{array}$} & \multicolumn{2}{|c|}{$\begin{array}{l}\text { Share in intra- Africa exports } \\
\text { in percentage }\end{array}$} & \multicolumn{2}{|c|}{$\begin{array}{l}\text { Share in world imports in } \\
\text { percentage }\end{array}$} \\
\hline & & 1995 & 2015 & 1995 & 2015 \\
\hline $\begin{array}{l}\text { Primary commodities, precious stones, and non-monetary } \\
\text { gold (SICT } 0,1 ., 971 \text { ) }\end{array}$ & 284435 & 7.69 & 88.05 & 17.29 & 76.33 \\
\hline Primary commodities excluding fuels (SICT $0+1+2,68$ ) & 83850 & 11.46 & 88.54 & 86.49 & 82.17 \\
\hline Primary commodities (SICT 0+1+2,68) & 68211 & 9.77 & 88.36 & 82.38 & 77.14 \\
\hline Food, basic (SICT 0+22+ 4) & 34684 & 13.65 & 60.56 & 11.82 & 83.76 \\
\hline $\begin{array}{l}\text { Food, basic excluding tea, cacao, coffee, and spices (SICT } \\
0+22+4)\end{array}$ & 23244 & 17.86 & 69.30 & 10.67 & 89.03 \\
\hline Beverages and Tabaco SICT1 & 2838 & 27.51 & 59.20 & 29.87 & 67.35 \\
\hline Agricultural raw material SITC 2, less 22,27 and 28 & 9490 & 11.74 & 90.82 & 15.13 & 88.39 \\
\hline
\end{tabular}

Source: UNCTAD calculations based on UNCTAD, UNCTADstat Merchandise Trade Matrix data. 


\section{Literature Review}

\subsection{Studies on Africa Regional Integration Trade}

Regional integration and the internal market growth plays an important role in the Africa development. however, Africa's market trends and the emergence of a middle class make the continent an increasingly interesting market in intra - African trade bears particular potential for growth. While trade within the African integration communities recorded average growth of 15 percent over the past decencies, intra - African exports grew even faster with $25,14 \%$ this indicates is that the regional integration communities' organizations does not perfectly on the internal trade flows. Regional economic integration across the world accelerates growth and development by bringing a wide array of benefits associated with enhanced political cooperation, increased intra-regional trade, and job creation. In times of global economic downturn, more integrated regions have shown faster growth and have shown great resilience on regional trade given greater approach with potential trade than foreign exports to contribute on value added, creation employment about $41.3 \%$ in (2013) comprised finished products compared to $14.5 \%$ of exports to the rest of the world.

Global economy ten years ago, struggle to regain high levels of growth Stimulating internal and regional growth has become the main political solution for many countries and regions. (see Figure 1).

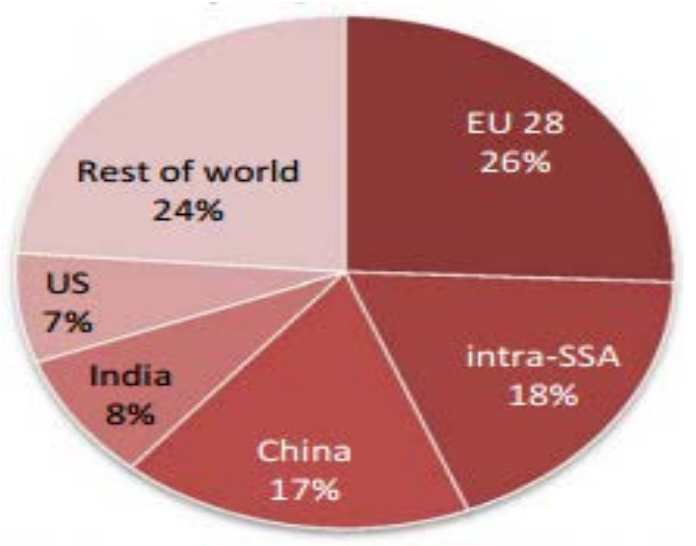

Figure 1. Africa 's total merchandise exports main destinations, (2014) (Source: UNCTAD 2014)

Today European Union is followed by China (17 percent), which played virtually no role at all in 1995 and China is increasingly forging ties with its neighbors, India is doing the same, (with 8 percent of African exports) has overtaken the United States. and even in the EU intraregional trade is returning to its pre-financial crisis levels. Hence in Africa, Morocco and South Africa are also aggressively adopting regional trade strategies. Also, have remains Africa's main export market, Africa's trade with the Atlantic nations of Europe is decreasing as Africa looks to trade more with itself.

However, as Africa integrates into global value chains, trade with Europe can be expected to continue to increase while competition with Africa's other Atlantic neighbors south of the United States is likely to increase. West, Southern, and Eastern African countries appear to be the front-runners in terms of intra-regional trade. SADC, and Ecowas are the regions of Africa continents among the five regional economic communities, for all that this document contributes to a comparative analysis of the two major African RTAs, (ECOWAS and SADC's) regional integration trade with in trade partners including Asian countries. Thus, potential trade in Growth markets process in the global trade. There are only a few studies on regional trade African that use the gravity model.

Intraregional trade in Africa's total trade, the direct contribution of any trade deflection to overall trade performance is likely to be limited. According to [8], Trade by and between Sub-Saharan African countries is an important and resourceful research topic for a few variety of reasons for alternative theories on the impact of RTA membership. furthermore, the regional of potential trade contribution in Africa has been competition on theoretical and empirical foundations.

One of the intriguing Aspect Africa states, a Regional trade (RTAs) is extend, However, since was established in 1975, Ecowas facilitated trade among its member's countries as with other RECs, its main aim is to promote intra-regional trade in the economic integration in all fields of economics activities. [9] It is consisted of 15 countries members with a combine GDP 623billion US\$ in (2015), and total population estimated over 349 million. Among others Nigeria 's income is more than $70 \%$ than half of the population.

In 2014 GDP or Ecowas was 677 US dollars and Nigeria was represented 522 US dollars among others the average growth rate of ECOWAS region was $4.2 \%$ (DAESNU 2015). And (SADC) Southern Africa Development Community, was created in 1980 it was formed as a loose alliance of nine majority rule states in southern Africa.it is a region comprising 15 countries. It has great economic potential, based on both the potential for domestic production and regional and international trade. Also consists of 15 countries. GDP of SADC region was about \$ 650 billion about $40 \%$ of continental According to World Bank's Global Economic Prospects, the region is expected to grow 4, 2 percent this year, from 3,4 percent in 2014 billion in 2015 . and the total population was 305 million. As title example, sub-Sahara Africa GDP growth in oil production across a different region. Among a main pattern exports.

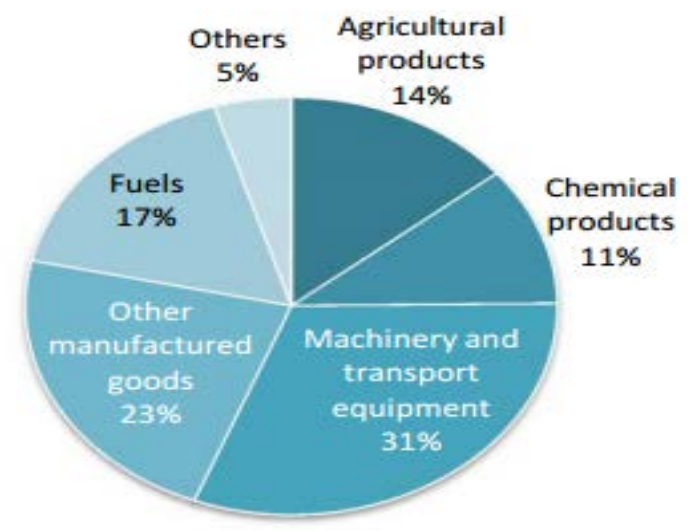

Figure 2. major imported product groups US\$406bn (Source: UNCTAD 2014) 
Table 2. Sub-Saharan Africa: Real GDP Growth, 2015 (Percent)

\begin{tabular}{lccccc}
\hline & World & United States & Euro area & Emerging markets & China \\
\hline 2015 projections & 3.5 & 3.1 & 1.4 & 4.3 & 6.8 \\
Revision from October 2014 & -0.4 & 0.0 & 0.1 & -0.7 & -0.3 \\
\hline
\end{tabular}

Source, World Economic Outlook database.

From the table showed in global the output is weak than in October the lower oil prices, however, are significant differences across region. For USA is strong, and has increased the likelihood of exit from unconventional monetary policy (UMP). Among sub-Saharan Africa's main trade partners, prospection on Euro zone is best with $0.1 \%$. China, the transition from an investment-led growth strategy is also expected to contribute to lower growth prospects- $0.3 \%$, and lower demand for Africa's exports. Finally, the dollar has appreciated substantially against the euro. This has implications for the region, where many countries have formal pegs to the euro, while a few others peg informally to the dollar.

As Generally, Integration regional partnership is thus defined as the result of a regional strategy replacing contiguous national spaces with a single space or in the process of unification. [10], showed the Regionalisms are often developed around a question Are regional agreements good or bad for international trade, for factor flow, and for optimal allocation of resources.

Africa integration process has had three phases, like [11] identify as a phase of integration of the market, the integration phase for cooperation, the process for the modalities of integration to development.

1-Market integration is for Africa has been summarize by [11], the main stages to market integration, first the preferential trade areas consist an agreement among members to reduce tariffs among each member than nonmembers. The second phase is to create the free trade areas between the members then maintain their own tariffs on nonmembers states. And thirdly, to create again a customs union which in the features a free trade in addition a common exterior tariff against nonmembers.

2- Regional Cooperation

Regional cooperation is the second stages of integration in sub-Saharan Africa that imply a strategy collaboration among two or more countries within interests similar, economic, political, social, and cultural interests [11]. Such Haarlov [12] show that the collaboration could encompass joint development projects and policies harmonization. If market integration is the eventual goal for states seeking for integration, Lee argues that regional cooperation is ideal establishing the economic integration foundations. Regional cooperation strategy target project or sectoral coordination of economic and physical infrastructures as developed. In fact, within Tips 2007 the inceptive procedure in SADC was more considered regional co-operation than with market integration [13].and in case of ECOWAS 2006 developed regional strategy and a plan of action to improve economic growth and reduce the poverty level.

3-And the development integration is a means by which take on to discourse the problems created by market integration. According to Haarlov [12] due to the problems of market integration such as the unfair sharing of integration benefits, development integration is followed with the goals of shifting the integration process, the timing and commitment levels of member-states, and the distribution of costs and benefits of integration. By means of these goals, the integration process encompasses not only economic cooperation, yet also social, and political integration.

\subsection{Africa Potential Trade}

The methodology concept of Africa potential trade has been extensively used by researchers studying international trade relations, particularly among eastern European countries, consists selecting a sample country for which trade is supposed to have reached its potential. Also, to investigate that the negative finding on African RTAs in the literature is integrated to a choice of a specific agreement or has a more general suitability. To measure trade integration of African countries, the ratios of intra-regional exports to total exports are examined as primary indicators of trade integration. As mentioned earlier, intra-regional trade is low in Africa relative to that of other regions. A high level of intra-African exports and imports indicate that a country has taken important steps to keep trade barriers with other African countries low (see Figure 3). Otherwise, the cost of trading would tend to render a country's products uncompetitive in other African markets and to reduce the proportion of a country's income spent on imports from the rest of Africa (UECA, UA, ADB, 2016).

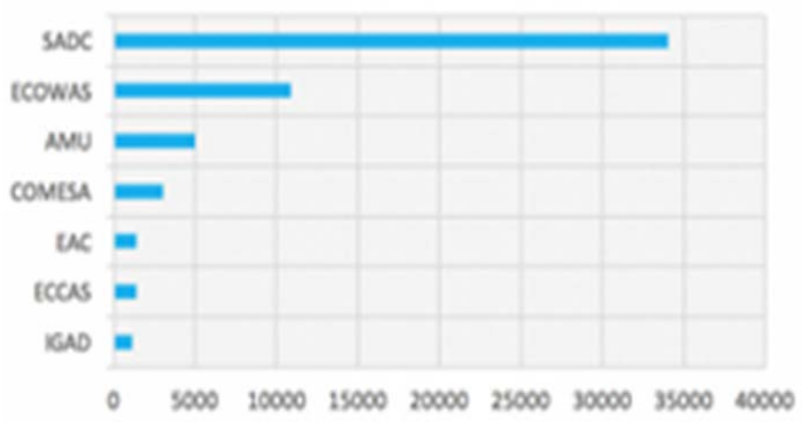

Note: Unrecorded flows across borders within Africa are likely to be larger than elsewhere in the world, and the reported numbers may not be fully accurate.

Figure 3. Share of intraregional trade in selected RECs (20 14*, in us millions) (Source: UN Comtrade, 2014)

\subsection{Evolution of Ecowas and SADC's International Trade}

Evaluation of Africa intra-trade flows and potential impact analysis of RECS, has been take on a long way. This study, therefore, builds on evaluating and analytical work on SADC and ECOWAS, Since ECOWAS and SADC are a different Organisation that do not have identic membership, a comparison of these two RTAs 
offers an appropriate system and unmistaken basis for an investigation of the impact of multi-membership. Recently, scholars as [14], are taken in interest on their research study on MIRAGE CGE model to calculate intra-African's potential trade flows without, the Continental Free Trade Area (CFTA) and the potential trade flows under a continental customs union. Keeping in view on their examples, in this paper taking two economic communities (ECOWAS and SADC) trade in the continent using panel regression model and theoretical gravity model in comparative case to uncover the main factors that influence behind the low level of intra-regional trade in Africa and the contribution of the existing regional economic communities

The liberalization of trade under the Continental Free Trade Area (CFTA) without addressing complementary TF measures and without removing non-tariff measures produced the following findings:

Intra-African trade in goods remains low, at around 10 per cent of total trade of Africa in 2010. Refers to (Figure 5) below, it shows the dynamism and strength of the economy potentials to improving intra-African trade that could come from the Continental Free Trade Area (CFTA), whereas more detail investigation of trade composition as requirement.

Relatively to the high applied tariff protection rate, about 8.7 per cent with heterogeneous tariff structures that range much higher in many case, UNCTAD's recent data shows intra-African trade share rising from about 9 per cent in 2000-2005 to 14 per cent in 2010 and reaching 18 percent in 2015.

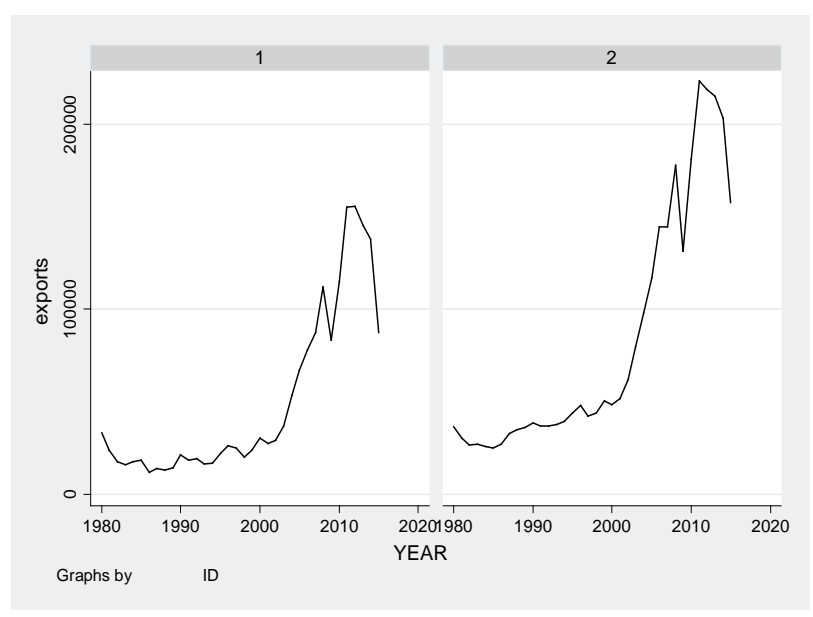

Figure 4. SADC/Ecowas merchandise trade flows, 2000-2015 (per US dollars) (Source: Author's own compilation from Stata)

In 2014 ECOWAS was the first region in Africa to conclude and officially endorse a regional Economic Partnership Agreements (EPA). It was followed by the SADC EPA group, when chief negotiators initialled the EPA at the same time, marking the conclusion of 12 years of negotiations on trade in goods with the EU. it is second best in this breakdown in terms of trade volume. Despite strides toward increased economic integration, the share of regional trade in ECOWAS has remained more or less constant, and significantly below the 40 percent target that the bloc aspires to reach by 2030 . However, Nigeria's weight in the region's total exports is very much dominated. These consist mainly of petroleum and commodity exports, which are largely directed toward the global market. According to [15], ECOWAS commodity exporters, The Gambia and Guinea join Nigeria with single digit numbers of intra-regional export shares as for the rest of ECOWAS member countries, regional trade plays a much more important role, with ratios as high as 59 percent in Togo, 41 percent in Senegal, and 31 percent in Niger. Exceptionally Nigeria exports to all regions are strongly because crude oil. Thus, there does not seem to be a clear-cut pattern across countries in terms of what is exported regionally and what is exported globally. Regarding trade composition, the export mix of goods to ECOWAS partners and to the rest of the world varies significantly among members. Development of regional value chains has been strongest in SADC and ECOWAS, measured as the imports and exports of intermediate and capital goods of each country with the rest of Africa as a share of GDP. This implies that these two regional economic communities may have stronger production networks than elsewhere in Africa.

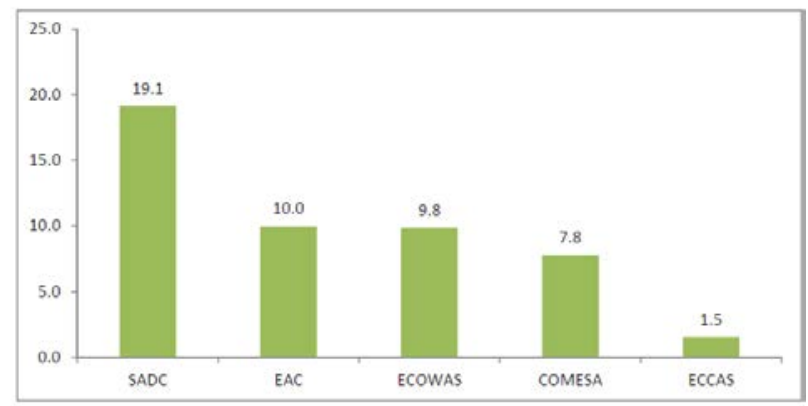

Figure 5. Share of intraregional trade in selected RECs (2014, in per cent) (Source: UNCTAD 2014)

The variation of the markets on trade flows, is highly closed, because relative on the minority export items mainly their primary products. Hence, for those economies percentage on each region show have a more diversified production base on the Africa local market for manufactured products is more important in overall trade.

As China is an incontestable influential partner with regards to all African Regional Economics comminutes (RECs). As Africa's first provider of infrastructure and, some estimates, has already pledged over US\$ 75 billion in infrastructure finance commitments, China's policy can effectively have adopted regional integration through both increased trade capacity and infrastructural development.

China in the 21st century, became the second largest trade partner with Africa, after the United States has influenced bi-lateral trade relations [16]. As illustration of how Chinese investment has been exploited. Hence in this paper its comparing Ecowas and SADCs regional integration. Chinese official policy toward Africa is a greater regional interconnection, with the Fifth Ministerial Conference of the Forum on China-Africa Cooperation FOCAC, (2011). The trade arrangements between china and the regional Africa trade like SADC/ECOWAS were established on trade forum in 2012, with SADC's region recently has been established in Infrastructure Investment Seminar in Beijing.is that cooperation promote the integration process of the RECs. SADC adduces together very harmonious states, but with enormous economic potential. These states are defined by the same economic 
structures apart from South Africa, and therefore, have this nature to market between them. But SADC is far from being a natural block in the sense of [18]. It depends heavily on trade relations and other types of cooperation with developed regions (such as the European Union, Asian, and the United States). On the other hand, SADC could be a natural area for agricultural and textile trade. Because the States which compose it are, for the most part, states in which agriculture dominates in their respective GDP (Namibia, Swaziland and Zimbabwe). And also, because, thanks to the partnership with the United States, through the AGOA act, the textile industry is evolving industrially in some countries like Swaziland or Lesotho which was in 2000 the third exporter of textile in the USA.

SADC has the fifth-highest intra-regional trade ratio worldwide among 32 regionals trading blocs. In particulars is not only the best-performing economic community in Africa, but also among the best performers in the world. Some of Africa's regional economic communities, however, perform strongly against other regional integration blocs in Africa and worldwide.

In the SADC region, the services sector represents more than half of GDP and remains the main driver of regional growth. Agriculture contributes about $15 \%$ of value added to GDP whilst industry makes up the remainder with just over $31 \%$. Total trade volume of SADC with the outside world has doubled in absolute terms between 2000 and 2009 Draft SADC RISDP, 2014. Moreover, endeavors to diversify exports have shown little success. Like china's involvements on the regional integration in Africa infrastructures projects remains strategic, specifically in relation to its resource exploitation and search for new markets for its construction companies in Africa.

Since 2009, China has become the largest trading partner in the world as well as SADC seems to have all the mechanisms in place to develop a China policy. SADC has a Policy Analysis and Dialogue Program which is intended to strengthen the Policy, Planning and Resources Mobilization (PPRM) strategies to exploit opportunities in co-operation with other regions of the world, has the potential to be harnessed in the interests of coordinating Chinese investments. Therefore, it cannot introduce a tariff common to all imports from abroad. For the time being, member countries have the freedom of their trade policy, even if bilateral negotiations and agreements proliferate in the region. Moreover, bilateral commitments take precedence over the multilateral agreement and, in addition, delay the complete abolition of tariff and nontariff barriers.

\subsection{ECOWAS, SADC's with China Trade Flows}

In a recent study, China's involvement in Africa trade partner, trade and development prospects have explicated mixed views regarding the economic relationship. Africa Development Bank Group in 2011, the most of African countries seeing China as the driver of Africa's structural transformation towards prosperity and higher economic growth, while some see the global economic emerging powerhouse marking Africa's efforts in industrializing itself and exploiting the continent's dependency on its naturally endowed resources. The market share of fuel and mineral in Africa's export trading display from 54 per cent in 2000 to $64 \%$ in 2012. Share of China in Africa fuel and mineral exports has increased from 11.8 percent from 2000 and 19 per cent in 2012 and is pointed as a factor helping to Africa's strengthen concentration in natural resource drawing out. In addition, sector since 2005, the Chinese in concessional financing have put around US\$5.4 billion and US\$8 billion in the Angolan oil sector in 2006, US\$3.5 billion in total investment in Gabon iron ore deposit. Some countries like Zambia, the trade unions has deepening precluded cheap goods imported from china in the country that were undermine its growth in the clothing and electrical sectors [19]. Benin had the highest percentage of the imports followed by Gambia, ore deposit in 2006, US\$800 million -1 billion investments in the Zambian copper industry since 2007 and US\$2.6 billion investment in the Liberian Bong mind iron ore deposit in 2008 [20]. However, ECOWAS imports from China also rose in 2005.Since 2013 Nigeria's Central bank governor declared in addressing at the bridges Africa Summit, that Chinese presence in Africa as a form of a system of economic domination, then persisted African countries to see the Asian power as a competitor. For further buttress the governor's statement, existing literature and empirical analysis from this article does show that the economic ties of regionally formed Economic Community of West African States (ECOWAS) and the south African Community (SADC) with China have a less effect on intra trade levels within the region's own members countries.

Table 3. Regional African trade (\% of GDP) of trade flows with China and regional trade group

\begin{tabular}{|c|c|c|c|c|c|c|c|c|c|c|c|}
\hline Countries & 2005 & 2006 & 2007 & 2008 & 2009 & 2010 & 2011 & 2012 & 2013 & 2014 & 2015 \\
\hline (SADC)China & 1.905 & 3.532 & 18.806 & 29.501 & 24.236 & 34.306 & 42.866 & 58.460 & 56.852 & 42.165 & 24.795 \\
\hline UE & 30.374 & 35.082 & 40.749 & 47.191 & 37.152 & 42.396 & 53.057 & 52.433 & 54.608 & 50.988 & 42.938 \\
\hline USA & 9.089 & 11.691 & 13.865 & 17.150 & 12.298 & 13.449 & 16.986 & 17.430 & 16.744 & 16.124 & 13.214 \\
\hline Africa & 12.941 & 19.508 & 21.999 & 27.281 & 24.390 & 44.619 & 51.459 & 58.002 & 54.899 & 51.789 & 39.372 \\
\hline Japan & 3.694 & 4.598 & 5.311 & 5.580 & 3.309 & 4.652 & 5.255 & 5.232 & 4.776 & 4.494 & 3.578 \\
\hline World & 10.343 & 11.953 & 13.777 & 15.972 & 12.317 & 15.064 & 18.073 & 18.459 & 18.957 & 18.969 & 16.508 \\
\hline (Ecowas)China & 3.968 & 5.312 & 7.314 & 10.665 & 15.085 & 19.811 & 25.786 & 26.782 & 27.717 & 32.429 & 31.793 \\
\hline UE & 18.414 & 20.808 & 18.205 & 26.747 & 22.358 & 29.954 & 52.535 & 67.827 & 53.481 & 56.701 & 33.388 \\
\hline USA & 30.718 & 33.665 & 31.466 & 44.032 & 23.486 & 42.767 & 53.253 & 46.058 & 20.584 & 16.162 & 8.715 \\
\hline Africa & 9.293 & 12.547 & 11.051 & 18.375 & 16.989 & 20.694 & 30.329 & 29.241 & 23.902 & 21.022 & 13.901 \\
\hline Japan & 1.831 & 1.695 & 2.195 & 2.561 & 2.378 & 2.996 & 4.348 & 3.395 & 2.746 & 2.089 & 1.540 \\
\hline World & 10.434 & 11.953 & 13.777 & 15.972 & 12.317 & 15.064 & 10.073 & 18.459 & 18.957 & 18.569 & 16.508 \\
\hline
\end{tabular}

Source: Author own calculation, (2017) based on ITC calculations, UN COMTRADE statistics.

Note: The world aggregation represents the sum of reporting and non-reporting countries. 
Trends of Africa's international trade in services are similar, the exportation Services are increased from Africa seven-fold between 1980 to 2010, and share of total merchandise and services trade to of 10 percent to 18 percent. In this table, we based on experiences WTO (2011) to explain this output, as China became the second largest importer of non-fuel materials such as iron ore and copper ore after the EU in 2010 over US. China's trade within ECOWAS, SADC have a significant positive effect on the intrabloc levels of trade increasing by the Chinese with both regions has mainly been in primary commodities, with that tendency has to make the regions dependent of foreign country for primary commodities. Thus, from the green part of the table indicate ECOWAS/SADC's flux intra-REC imports have also shown a growing trend in recent years, trading relationship with China ,2013 and 2012, intra-REC imports averaged 58.4 et 56.8 percent in SADC, 31.15 et 26.7 percent in 2103,2015 in ECOWAS. A significant portion of imports for each REC were destined for countries in SADC, 56.8 percent in 2013 of imports were destined for China. Due in SADC, representing a considerable movement towards greater concentration in highly exports concentrated on a few products, mainly primary and some manufacturing commodities, which has the propensity to then make the region dependent on the foreign country for such primary commodities. Thus, from the green part of the table indicate ECOWAS/SADC's flux intra-REC imports have also shown a growing trend in recent years, trading relationship with China ,2013 and 2012, intra-REC imports averaged 58.4 et 56.8 percent in SADC, 31.15 et 26.7 percent in 2103,2015 in ECOWAS. A significant portion of imports for each REC were destined for countries in SADC, 56.8 percent in 2013 of imports were destined for China.

Due in SADC, representing a considerable movement towards greater concentration in highly exports concentrated on a few products, mainly primary and some manufacturing commodities.

High lightly detail with some measures and policy reforms in econometrics analysis is given in this research article.

\section{Theoretical Foundations Justifications and Specification}

There are various techniques and process for assessing regional trade. [21] Among these, the gravity model is a simple tool often give in good results in predicting bilateral.

\subsection{Evaluation of Potential Trade Using Gravity Model: A Literature Review}

The gravity model for scholars as Newton's Law of Universal Gravitation, Bergen (1962) and Poyhonen (1963) are the pioneered of the gravity theories use the concept in international trade. In their research on the gravity model, explained existence analogy between gravitational attraction between two bodies being determined by their mass and distance between them, in the gravity model there exists analogy between gravitational attraction between two bodies existence determined by their mass and distance between them,

bilateral trade flows are fundamentally to be established by the national incomes of the exporting and the importing countries (economic mass), the distance between them. The analogy with physics given the following equation as: $\mathbf{G F}=\mathbf{A} \cdot \frac{M 1 \cdot M 2}{\mathbf{D} 2}$, where: GF, equal to force gravitational, A represent a constant, $\mathrm{M}$ (mass of planets gravitation), $\mathrm{D} 2$ is the distance between them.

While, this equation represents the transformation from applied in international trade by Jan Tinbergen's (1962), original foundation the gravity equation noted that Bilateral trade flows depend on the size of economies measured by GDP and transportation costs approximated by the distance between countries linked by trade relationships:

$$
\begin{aligned}
& \text { As follow the equation } \\
& \Rightarrow \text { tradeij }=\alpha \frac{G D P i^{\beta} * G D P j^{\alpha}}{\text { Distance } \mathbf{i j}} .
\end{aligned}
$$

where

Tradeij = represent import and exports,

$\alpha$ : Constant; and GDPij: Gross domestic products.

The augmented version of the gravity model takes into account other factors that influence trade:

a) The level of economic development measured by per capita income (which influences trade through consumers purchasing power);

b) Cultural factors (common language, common colonizer) that influence consumption patterns;

c) Common border and trade agreements (that reduce barriers to trade); etc.,

This equation is often transformed into linear form so that it conforms to the usual regression analysis:

$$
\begin{aligned}
\log (\text { trade } \mathrm{ij})= & \alpha+\beta 1 \log \left(\mathrm{GDP}^{\mathrm{i}} . \mathrm{GDPj}\right) \\
& +\beta 2 \log (\text { distance })+\varepsilon \mathrm{ij} .
\end{aligned}
$$

The augmented gravity model can be specified as follows:

$$
x \mathbf{i j}=\alpha 0+\mathrm{Yi}+\mathrm{Yj}+\mathrm{yij}+\mathrm{Dij}+\mathrm{pij}+\mathrm{uij}
$$

where:

tradeij: Exports of country i to country j;

y: Per capita income;

Y: GDP;

D: Distance between partner countries;

P: Dummy variable measuring trade preferences;

u: Error term.

The theoretical basis of the model of gravity, has had a considerable empirical success it in view of the fact that, its ability to predict bilateral trade. However, there was several studies on gravity model knowledge such as, [22,23], bear on Armington's assumption on product differentiation by country of origin. And considered the analysis part of all goods are exchanged. Each country involved their exchange consumes a little of all goods produce in other countries such as transportation costs, decreased trade exchanges, they considered that the parts 
results of analysis for all goods are exchanged. [24] Armington's (1989) show that the assumption restrictions are lifted as soon as reason in a context of monopolistic competition, Business location is then endogenous for countries specialize on a production of a range of goods. Moreover, some undertakes have been made to explore its relationships with the fundamental elements of trade speculation, and are reviewed below. Some scholars used gravity model explains international trade following different approaches consequently, [25] used for the law of factor proportions, while [26] have used a model of monopolistic competition. [27] used the gravity equation in his study "estimating trade flows, trading partners and trading volumes". Had developed a simple model of international trade with heterogeneous firms that is consistent with a number of stylized features of the data. Specificity the model on prediction positive as well as zero trade flows across pairs of countries, and it allows the number of exporting firms to vary across destination countries. by [28] used in study Distorted Gravity in the Intensive and Extensive Margins of International Trade introduce firm heterogeneity in a simple model of international trade. According to [29] based their analysis on geographical in Xiniang's regions made quantitative analysis to evaluate trade performance with 34 countries as observations, they mentioned there are two indices, which can be appropriately used to as a good measures of trade performance. Their results showed that, Xinjiang had already established strong trade ties with Central Asia, Central and Eastern Europe, and Western Europe. [30], mentioned the Applications of the gravity model are especially used to explain and predict the effects of regional trade agreements on the creation and diversion of trade, and the trade policy developments, and other factors that affect trade, such as natural border. Effects, foreign direct investments, transportation costs, GDP, democracy effects, regulatory quality, export performance and north versus south effects. However, according to Linder hypothesis using the gravity model, countries with similar levels of income have been shown to trade more, and these countries are trading in different goods because of their similarities [31]. The gravity model has been empirically used to measure the impact of integration economic on trade flows or in the impact of common borders on trade. Regarding the functional form, it's used to calculate trade potential among countries. And in this case, it is use to estimate the trade potentials of Africa and China.

\subsection{Trade Potential Calculation}

The calculation of the commercial potential depends on the results of the gravity model. The gravity model used to estimate trade determinants in SADC and ECOWAS included some countries outside China. In the study of potentials trade between savings heterogenous [32] used this methodology below to calculate trade potential. Three approaches are identified to measure commercial potential as follows, A) estimating a gravity model on a sample of countries, b) calculation of simulated trade flows from the estimation results of the model; c) calculating the adjusted simulated flows; d) computation of trade potential as the average of gross simulated flows and adjusted simulated
Adjusted exports, denoted $\mathrm{Xij}^{*}$, are given by the following equation:

$$
\mathrm{Xij}^{*}=\frac{X^{\wedge} * i j \sum \int(X i j-X i j)}{\sum \int\left(\mathrm{X}^{\wedge} \mathrm{ij}{ }^{*} \mathrm{X}^{\wedge} \mathrm{ij}\right)}
$$

$\mathrm{X}^{\wedge}$ : Simulated exports.

$\mathrm{X}^{\wedge} *_{\mathrm{ij}}$ represents gross simulated bilateral trade flows, those directly obtained from model estimation, $X i j$ the observed bilateral trade level and $X * i j$ the adjusted simulated trade flows. The second step is to calculate the commercial potential (CP) for a given period as an Arithmetic mean of crude simulated flows and adjusted simulated flows:

$$
\mathbf{P C i j t}=\frac{1}{2}\left(\mathbf{X}^{\wedge} i j t+\mathbf{X}^{*} i j t\right) .
$$

\subsection{Estimation of the Trade Potential of Africa and China}

The model used is an augmented version of the gravity model. It is specified as follows:

$$
\begin{aligned}
& \log \mathrm{X}_{\mathrm{ij}}=\alpha 0+=\alpha 1 \operatorname{logGDP} \mathrm{P}_{\mathrm{it}}+\alpha 2 \text { GDPjt }+\alpha 3 \log \mathrm{ijt} \\
& +\alpha 4 \log \text { GPCijt }+\alpha 5 \mathrm{EU}+\alpha 6 \text { China }+\alpha 7 \mathrm{SADC} \\
& +\alpha 8 \text { ECOWAS }+\alpha 9 \text { Contiguity }+\alpha 10 \text { Langcom } \\
& +\alpha 11 \text { Langloc }+\alpha 12 \text { Coloncom }+\alpha 13 \text { Indust }+ \text { uijt. }
\end{aligned}
$$

The specification retained is in the log-linear form. The dependent variable is the level of exports (Xij) and it is assumed to be explained by factors found in literature:

- Production level measured by GDP of partner countries that measures the size of the market influences positively trade flows;

-The distance (D) is a proxy for transportation costs and has a negative impact on trade flows;

-The surface (Superf) of countries participating in trade is an important indicator of domestic market which influences negatively international trade;

- A dummy variable (contiguity), taking the value 1 or 0 depending on whether countries share border or not captures border effect;

- Cultural factors are taken into account through dummy variables representing the existence of a common official language (Langcom);

-Membership in the West African Economic and Southern Union (SADC) which is measured by a dummy variable. In addition, other variables that could facilitate (or hinder) trade are also taken into account such as:

- Credit to private sector in percentage of GDP (credit);

- Industrialization level (indus) measured by the share of industry in GDP;

- The average per capita power consumption (kg of oil) (energ) reflecting the level of economic development;

-Inflation which provides information on macroeconomic stability.

\subsection{Data Source}

The study includes southern and western African countries of origin and their countries of destination from different regions of the world. Trade flows data are from the 
UNCTAD dataset, distance and dummy variables data are extracted from the CEPII data base and GDP per capital from The World Bank database (World Development Indicators). The data cover the years 1980 and 2015, GDP per capital, distance, borders, trade openness (per pattern and Africa), GDP, population in (consensus Governments (2017), commun language partner. From 2005 to 2015 trade flows data between SADC/ECOW'S regions and China and others partners in UNCTADstat.

\section{Results and Interpretations}

The model variants are estimated, the dependent variables being successively imports, exports and total trade. The estimate of the first model (Table 5) makes it possible to identify blocks of variables: the block of the traditional variables (PIB, POP, Dist.,), the block of resistance variables multilateral (P, Infl), the block of control dummy variables (contiguity, comlanguage, ethinq,) and the block of dummy integration variables (SADC, ECOWAS, China, others partners). In the case of traditional variables, the results show the signs expected in accordance with the theory. Thus, whatever the variable dependence, the country's GDP i contributes positively and significantly to $4 \%$ in its bilateral trade. Indeed, the increase in income induces an additional purchasing power. This additional purchasing power imports, increases the means of production with a multiplier effect on the production and volume of exports and, consequently, on total trade from the country. A similar analysis can be conducted for country $\mathrm{j}$. Populations is significantly increased. In the case of imports, the population of country i, when increases, acts as an indicator of market size that can absorb imported products. Taking the case of exports, a positive sign is justified also makes explicit the fact that the population of country $i$ is an approximation of the labor force and acts as a fundamental determinant of production and hence the export of that country. As regards the population of country $\mathrm{j}$, it is a significant vector of commercial integration whether in terms of imports, exports or total trade. Finally, distance plays its role of gravity for bilateral trade, even if the sign does not become significant than in the case of total trade. This result implies that all things being equal Moreover, increasing the distance of one unit between two countries reduces their total bilateral trade of 0.41 units. These results are in line with those obtained in some previous works [28,32] With regard to exports, a high-level inflation in the country $\mathrm{i}$ demoralize the economic operators of the partner countries, who apprehension fear to import this negative shock into their economies. There is a substitution effect in the partner countries of goods imported by domestic goods, even if they are of inferior quality. Indeed, foreign inflation hampers domestic purchasing power in the face of foreign goods. The fact that trade in the country increases with its inflation could be explained by the fact that its partners, despite transaction costs that would theoretically be high in that country, increase their margins. It is therefore the arbitration between the increase in margins and the level of transaction costs in country $\mathrm{j}$ which justify this sign. The dummy control variables give expected and significant coefficients, except for the common language variable that tends to significantly degrade bilateral trade in ECOWAS and SADC. This could be explained by the fact that countries speak several languages (French, English, and Spanish), including national languages. If we add to this plurality of languages those of other trading partners, this variable can only deteriorate bilateral trade.

Table 4. Exports as dependent variable

\begin{tabular}{|c|c|c|c|}
\hline variables & Pooled model & Random effect model & Fixed effects model \\
\hline _constant & $-8.994812(-0.38) *$ & $-8.9947(-0.38)^{*}$ & $-.027329(-0.02)^{* * *}$ \\
\hline GDPi & $.47619(5.64)$ & $.47619(5.64)$ & $.47619(5.64)^{*}$ \\
\hline import & $.314593(3.46)^{* * *}$ & $.314593(3.46)^{* * *}$ & $.314593(3.46)^{* * *}$ \\
\hline popi & $.136624(0.36)$ & $.136624(0.36)$ & $136624(0.36)$ \\
\hline DISTCEi & $-2.195706(-0.41)$ & $-2.195706(-0.41)$ & $-2.195706(-0.41)$ \\
\hline Inflt & 0567064(4.17) & $0567064(4.17)^{*}$ & 0567064(4.17) \\
\hline Adjusted R-squared & & 0.9659 & 0.9657 \\
\hline F-test & & & $0.6847 * * *$ \\
\hline Number of obs $=$ & 72 & & \\
\hline Prob $>$ chi $2=$ & 0.0000 & & \\
\hline alpha & $1.000002(1.62)$ & & \\
\hline
\end{tabular}

Note: $* * *, * *, *$, significant at $1 \%, 5 \%$ et $10 \%$, t-statistic are in parentheses the variables are in log. alpha is linear prediction value.

Table 5. Hausman test

Coefficients

\begin{tabular}{|l|c|c|c|}
\hline Items & $\begin{array}{c}\text { (b) } \\
\text { random }\end{array}$ & $\begin{array}{c}\text { (B) } \\
\text { fixed }\end{array}$ & $\begin{array}{c}\text { (b-B) } \\
\text { Difference }\end{array}$ \\
\hline GDPi & .4761996 & .4761996 & $2.83 \mathrm{e}-10$ \\
\hline import & .314593 & .314593 & $-4.27 \mathrm{e}-10$ \\
\hline popi & .136624 & .136624 & $1.88 \mathrm{e}-09$ \\
\hline inflation & .0567064 & .0567064 & $-3.26 \mathrm{e}-11$ \\
\hline alpha & 1.000002 & 1.000002 & -0000369 \\
\hline
\end{tabular}

$\mathrm{b}=$ consistent under Ho and Ha; obtained from xtreg

$\mathrm{B}=$ inconsistent under Ha, efficient under Ho; obtained from xtreg

Test: Ho: difference in coefficients not systematic chi2(3) $=(b-B)^{\prime}\left[\left(V \_b-V \_B\right)^{\wedge}(-1)\right](b-B)=0.00$

Prob $>$ chi2 $=1.0000\left(V \_b-V \_B\right.$ is not positive definite). 
The model variants are estimated, the dependent variables being successively imports, exports and total trade. The estimate of the first model (Table 4) makes it possible to identify blocks of variables: the block of the traditional variables (GDP, POP, Dist.,), the block of resistance variables multilateral (P, Infl), the block of control dummy variables (contiguity, comlanguage, ethinq,) and the block of dummy integration variables (SADC, ECOWAS, China, others partners). In the case of traditional variables, the results show the signs expected in accordance with the theory. Thus, whatever the variable dependence, the country's GDP i contributes positively and significantly to $4 \%$ in its bilateral trade. Indeed, the increase in income induces an additional purchasing power. This additional purchasing power imports, increases the means of production with a multiplier effect on the production and volume of exports and, consequently, on total trade from the country. A similar analysis can be conducted for country j. Populations is significantly increased. In the case of imports, the population of country $i$, when increases, acts as an indicator of market size that can absorb imported products. Taking the case of exports, a positive sign is justified also makes explicit the fact that the population of country $\mathrm{i}$ is an approximation of the labor force and acts as a fundamental determinant of production and hence the export of that country. As regards the population of country $\mathrm{j}$, it is a significant vector of commercial integration whether in terms of imports, exports or total trade. Finally, distance plays its role of gravity for bilateral trade, even if the sign does not become significant than in the case of total trade. This result implies that all things being equal Moreover, increasing the distance of one unit between two countries reduces their total bilateral trade of 0.41 units. These results are in line with those obtained in some previous works who apprehension fear to import this negative shock into their economies. There is a substitution effect in the partner countries of goods imported by domestic goods, even if they are of inferior quality. Indeed, foreign inflation hampers domestic purchasing power in the face of foreign goods. The fact that trade in the country increases with its inflation could be explained by the fact that its partners, despite transaction costs that would theoretically be high in that country, increase their margins. It is therefore the arbitration between the increase in margins and the level of transaction costs in country $\mathrm{j}$ which justify this sign. The dummy control variables give expected and significant coefficients, except for the common language variable that tends to significantly degrade bilateral trade in ECOWAS and SADC. This could be explained by the fact that countries speak several languages (French, English, and Spanish), including national languages. If we add to this plurality of languages those of other trading partners, this variable can only deteriorate bilateral trade.

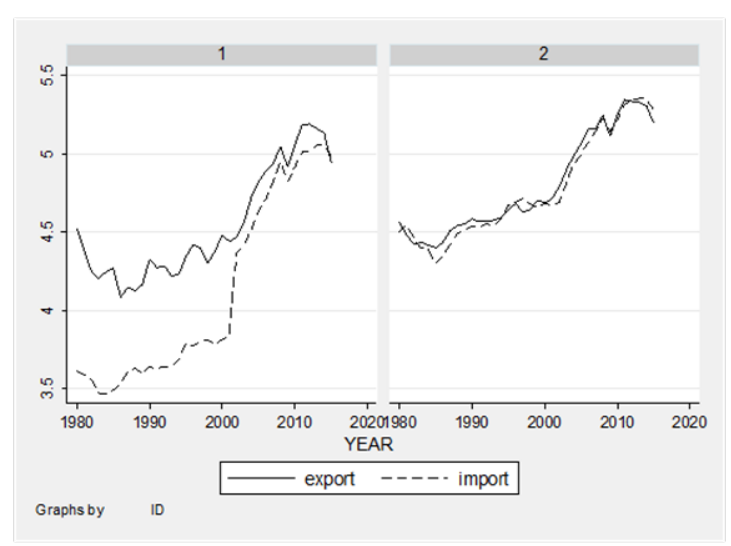

NB: it is remarkable; these results are similar since the realities of the African countries are almost the same in terms of trading partnerships.

Figure 6. Exports/import with Africa (Source: Author's compilation in Stata from trade Data between China and regional Africa.)

Table 6. Import as indepent variable

\begin{tabular}{cccc}
\hline variable & Pooled model & Random model & Fixed model \\
constant & $-196.0414(-11.07) * * *$ & $-196.0414(-11.07) * * *$ & $-15.18153(-11.50) * * *$ \\
GDPi & $3914807(3.09)$ & $.3914807(3.09) *$ & $3914807(3.09)$ \\
export & $.535734(3.46)$ & $535734(3.46) * *$ & $535734(3.46)$ \\
POPi & $2.988637(10.07)$ & $-.2328745(10.07)$ & $-.2328745(10.07)$ \\
DISTCEi & $44.28408(11.00)$ & $44.28408(11.00)$ & $-.0687351(-3.80)$ \\
Inflation & $-.0687351(-3.80)$ & $-.0687351(-3.80)$ & $13409.23(0.95)$ \\
ethinq & & $-25157.1(-1.34) * *$ & $-23030.71(-1.35)$ \\
language & & $-2488.736(-0.14)$ & $11481.91(0.67)$ \\
landlocked & 0.9784 & 0.9689 & 0.9689 \\
R-sq & 72 & & \\
Number of obs & $=0.00$ & & \\
Prob $>$ chi2 & $=460.18 * * *$ & & \\
F-test & & &
\end{tabular}

Notes: $* * * * * / *$ significant at $1 \% / 5 \% / 10 \%$ level the t-statistics are in parentheses

Table 7. Hausman test

---- Coefficients ----

\begin{tabular}{|c|c|c|c|c|}
\hline & $\begin{array}{c}\text { (b) } \\
\text { random }\end{array}$ & $\begin{array}{c}\text { (B) } \\
\text { fixed }\end{array}$ & $\begin{array}{c}\text { (b-B) } \\
\text { Difference }\end{array}$ & sqrt(diag(V_b-V_B)). S.E. \\
\hline GDPi & -.2769236 & .3914807 & -.6684044 & .145399 \\
\hline import & 1.808522 & .535734 & 1.272788 & .088752 \\
\hline POPi & -.2328745 & 2.988637 & -3.221512 & .0113392 \\
\hline inflation & -.0573959 & -.0687351 & .0255269 \\
\hline
\end{tabular}

$\mathrm{b}=$ consistent under Ho and Ha; obtained from xtreg

$\mathrm{B}=$ inconsistent under Ha, efficient under Ho; obtained from xtreg

Test: Ho: difference in coefficients not systematic chi2(3) $=(b-B)^{\prime}\left[\left(V_{-} b-V \_B\right)^{\wedge}(-1)\right](b-B)=-123.77$ chi2 model fitted. 
Table 8. Evaluation and Analysis of Potential trade between China SADC, ECOWAS and partners

\begin{tabular}{lccc}
\hline Variables & Pooled model & Random model & Fixed model \\
\hline CHINA-SADC & $13.04947(1.09)$ & $13.04947(1.09)^{* *}$ & $30.01971(3.86)^{* *}$ \\
CHINA-ECOWAS & $26.36746(3.80)^{* * *}$ & $26.36746(3.80)$ & $12.04476(1.01)^{* * *}$ \\
USA & $2.885095(-0.92)$ & $-2.885095(0.92)$ & $-9.375146(-1.34)^{* *}$ \\
JAPAN & $-12.61889(-1.70)$ & $-12.61889(1.70)^{* *}$ & $-2.079766(-0.16)^{* *}$ \\
UE & $4.241533(0.58)$ & $4.241533(0.58)$ & $-1.60121(-0.17)^{* * *}$ \\
_Cons & $-86.12165(-3.28)^{*}$ & $-86.12165(-3.28)^{*}$ & $-66.982(-2.09)^{*}$ \\
R2 & 0.8377 & 0.8118 & 0.8234 \\
DISTCEi & $-44.28408(11.00)$ & $-44.28408(11.00)$ & $-44.28408(11.00)^{* *}$ \\
Prob>F & 0.0000 & $0.0000^{* * *}$ & 0.0000 \\
Observations & 22 & & 0.3174 \\
F test & & & 82.57 \\
Wald chi2 & & & \\
\hline
\end{tabular}

Note: $\operatorname{In}(\log )$ trade GDP the observation data is from 2005 to 2015, *, **, ***: significative à $1 \% 5 \%$ et $10 \%$

Source: Built by the authors, from Stata.

It emerges from this Figure 6 indicates that Ecowas (1) and SADC (2) trade exchange of the two-level import / exports with china, the level of SADC is more important than Ecowas. It is clear that in the Figure 3, 3.5; unites to 4.5 represent trade flows of Ecowas with its partners and 4.5to 5.5 unites to Figure 4 for SADC.

The estimation is simulated to determine the within potential sum trade meant import and exports of products. The estimated exports are compared GDP of actual exports-import in order to see if there is unexploited trade potential. For these countries, it was indicated that the potential exports were highly significant at $1 \%\left(3.80^{* * *}\right)$ between China and ECOWAS; On the same logic, it was fund that between China and SADC, it was Significant at $5 \%\left(3.86^{* *}\right)$. However, the results show that in terms of partnership trade, the potential trad was highly significant at $1 \%$ level between these two institutions (SADC, ECOWAS), however, JAPAN and USA have an important potential trade significant at $5 \%\left(-1.34\right.$ and $\left.-0.16^{* *}\right)$ respectively. Specifically, experiences of trade creation tend to dominate those of trade destruction. Significant trade-creation experiences relate to the bilateral flows China-SADC, China-ECOWAS, EU-China, and USAChina. As for the destruction episodes, they involve China-Japan, China-EU it is important to promote exports to these countries in order to exploit unexploited trade potential. However, a further analysis of each country is important in order to determine and identify possible factors that may inhibit export potential. The analysis is completed by describing the potential for trade creation or predicting trade performance in SADC and ECOWAS. This indicator is calculated as the difference between observed trade and trade potential. If it is positive or negative, there is a creation (destruction) of exchanges, that is to say that countries exchange beyond their level of full use of commercial capacities. Was giving by [24,33] evaluated trade performance prediction using the Relative difference (Rd) Index. The index was computed as expressed in equation (7), while using the mean predicted trade value together and the and the mean actual trade value.

$$
x=(\psi \text { ijlt }+\varphi \text { ijlt }) * 100 \backslash(\psi i j l t+\varphi \text { ijlt })
$$

Where: Rdijlt denotes relative difference of each regional state's trade flows with trade partner j. $\psi$ ijlt refers to the mean actual trade and $\varphi$ ijlt is the mean predicted trade. The index varies between -1 and 1 , and it gives an insight into the future direction of trade [24]. Positive values imply that there exists good trade performance, an indication of cooperation between the trading parties. In light of measuring the trade performance of ECOWAS/SADC member states in exporting products into the partners market, the analysis employed is similar to that of [24,33].

The (Table 8) represent Specifically trade indicator, experiences of trade creation tend to dominate those of trade destruction. Significant trade-creation experiences relate to the bilateral flows China-SADC, ChinaECOWAS, EU-China, and USA-China. As for the destruction episodes, they involve China-Japan, China-EU and world-China flows to a lesser extent. This result confirms our intuition. This result confirms our intuition that ECOWAS countries and especially China trade globally beyond their potential, which describes a significant effort in this area. In total. China's involvement in the destruction of trade with ECOWAS shows the tendency of China's trade orientation towards the out-ofarea countries, but much more because it has exhausted its commercial potential to its partners.

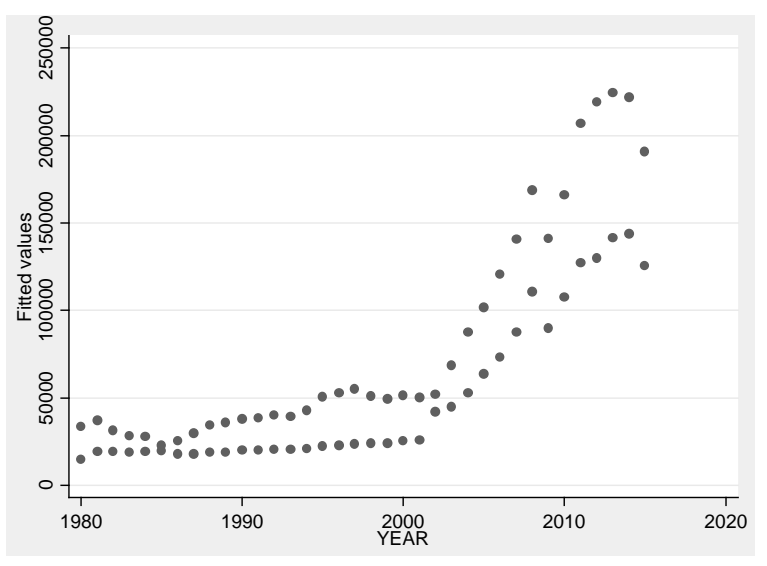

Figure 7. Indicate the prediction of trade flows between SADC and ECOWAS (Source: Author's own compilation from Stata)

The Figure 7 indicated the summrased trade flows between these two countries simple linear regression prediction alpha from 1980 to 2020.the relationship between these two countries should be true but not excat,it have to take this 
form: $\mathrm{Y}^{*}=\alpha^{*+} \beta^{*}+\mathrm{xi}+\varepsilon i^{*}, \varepsilon^{*}=\mathrm{y}-\left(\alpha^{*}+\beta^{*}+\mathrm{xi} i^{*}\right)$, the miminize sum of all deviation form the line (squared residualed)is done mathematically by the satistically program and hand.

The value of dependent variable(value on the line) are called predicted values of the regression.

From the figure, the prediction values have been standart from 1980 to 1990 , due in fact of factory level in $\mathrm{n}$ the tese countries judged very low at that period and stated increasing from 2000 to 2020 . It should be conclud that From 2000 to 2018, this level will increases due to the industry involving and some investment in agriculture sector and others. The oil spefically should increases the volume of regional trade in African conutries but so many challenges in terms of western countries which are mostly exploited these mining sites.

\section{Conclusion}

The market integration is plausibly a fundamental step in the economic integration process of a regional community. It was found that this study has been done through many variables computed from the research methodology where was observed export/import, GDP, inflation, distance, population, language. The Panel data analysis show that the potential trade was highly significant at $1 \%$ level (3.80***) between China and ECOWAS countries and significant at $5 \%$ level in SADC countries $\left(3.86^{* *}\right)$. In terms of partnership, the potential trade was highly significant from EU to ECOWAS/SADC with $5 \%$ level compared to JAPAN and USA.

In terms of international trade potential, from Figure 4, the prediction values have been standart from 1980 to 1990 , due in fact of factory level in $\mathrm{n}$ the tese countries judged very low at that period and stated increasing from 2000 to 2020. It should be conclud that From 2000 to 2018, this level will increases due to the industry involving and some investment in agriculture sector and others. The oil spefically should increases the volume of regional trade in African conutries but so many challenges in terms of western countries which are mostly exploited these mining sites. The prediction alpha has been done within all variables given 1.62 unites, meant in coming years will be this predicted. The result has been interpreted with carefulness that is necessary taking consideration of trade volume underground.

There has been some recent improvement, as indicated by estimates for the period 2005-2015, the actual trade of SADC/ECOWAS with China has slightly significant.

For this analysis of the estimated facts and the estimation of the determinants bilateral trade by means a gravity equation in its augmented version, an indicator of commercial potential has been evaluated the present study is empirically based and therefore relies heavily on the availability, completeness, and authenticity of the data. The gravity model in bilateral potential trade should have its strengths as well as limitations, naturally trade relations between different countries should be stronger if they are comparatively nearer, have common borders, a common language, close social relationship and Political affairs are sometimes more powerful than economic and commercial considerations. This estimation reveals that Africa has the highest trade potential with partners: China, USA, EU,
JAPAN. In any case, Africa will have to improve the quality of its exports and minimize the cost of production to enable it to compete well in the international market; these results illustrate the fact that African's trade within AFTZ is very low. the prospects on future trade expansion between regions can be conditional the political advancement to review their market conditions on some regions. So, whereas Africa's free trade zone (AFTZ) started in 2015 with some significant changes on custom tariffs and reduced trade related barriers and the trade liberalization in the region.

\section{Acknowledgements}

I would like to express my gratitude to Dr Siba. K. Koivogui, Associate professor in Institute Superior Agronomic and Veterinary Valery Giscard Destin of Faranah/Guinea whose expertise, understanding, and patience, added considerably to this article experience. I am heartily thankful Him, to encouragement, guidance and support from the initial to the final level enabled me to develop an understanding of the subject. Lastly, I offer my regards and blessings to all of those who supported me in any respect during the completion of the project.

\section{References}

[1] McCormick, J. (1999). The European UnionPolitics and Policies.

[2] Portugal-Perez, A., J.S. Wilson, (2012). Export performance and trade facilitation reform: Hard and soft infrastructure. World Development,vol 40(7): p. 1295-1307.

[3] Amita, K. (2004), Gate apparatus, on-board unit, setup method of the on-board unit, toll collecting method and judging method of the entrance and exit, Google Patents.

[4] Baldwin, R., (1994). Towards an Integrated Europe (Centre for Economic Policy Research, London).

[5] Nilsson, L., (2000). Trade integration and the EU economic membership criteria. European Journal of Political Economy, vol 16(4): p. 807-827.

[6] Armstrong, S.P., P. Drysdale, K. Kalirajan, (2008). Asian trade structures and trade potential: an initial analysis of South and East Asian trade.

[7] Abdoulahi, M. (2005). Évaluation des efforts d'intégration régionale en Afrique en vue de promouvoir le commerce intra africain. Centre africain pour les politiques Commerciales, CEA N, .vol 30: p. 691-751.

[8] Yang, Y. , M.S. Gupta. (2005). Regional Trade Arrangements in Africa: Past Performance and the Way Forward (EPub) International Monetary Fund.

[9] Olayiwola, W.K., O.A. Ola-David. (2013). Economic integration, trade facilitation and agricultural exports performance in ECOWAS member states. in Presentation at the Eighth African Economic Conference on'Regional Integration in Africa', Johannesburg, South Africa.

[10] GEMDEV, 1999, La Mondialisation: les mots et les choses, Paris, Karthala. Pp 350

[11] Y.S. Lee, (2003), Reflections on U.S. International Trade Law and Practice: Compatibility with the WTO Rules and Call for Modification,” Currents: International Trade Law Journal, Vol. 13, No. $2,31-43$

[12] Jens Haarlow, (1997). Regional Cooperation and Integration within Industry and Trade in Southern Africa: General Approaches, SADCC and the World Bank. Aldershot: Averbury, p. 16.

[13] Söderbaum, F. (1996). Handbook of regional organizations in Africa Nordiska Afrikainstitutet.

[14] Mevel, S., S. Karingi. (2012). Deepening regional integration in Africa: A computable general equilibrium assessment of the 
establishment of a continental free trade area followed by a continental customs union. in 7th African Economic Conference, Kigali, Rwanda.

[15] CONDE, C., P. HEINRIGS, A. O'SULLIVAN. (2015). Tapping the Potential of Global Value Chains for Africa. Europe, vol. 57: p. 50.9.

[16] Carmody, P. , I. Taylor. (2010). Flexigemony and force in China's resource diplomacy in Africa: Sudan and Zambia compared. Geopolitics, vol. 15(3): p. 496-515.

[17] Krugman, P. (1991). Increasing returns and economic geography. Journal of political economy, vol. 99(3): p. 483-499.

[18] Ancharaz, V., T. Kandiero, and K. Mlambo. (2010). The First Africa Region Review for EAC/COMESA, African Development Bank.

[19] UNECA, U., A. AfDB. (2011). Assessing Progress in Africa toward the Millennium Development Goals. MDG Report.

[20] Frankel, J.A., E. Stein, S.-J. Wei. (1997). Regional trading blocs in the world economic system: Peterson Institute.

[21] Anderson, J.E. (1979). A theoretical foundation for the gravity equation. The American Economic Review, vol. 69(1): p. 106-116.

[22] Bergstrand, J.H. (1985). The gravity equation in international trade: some microeconomic foundations and empirical evidence. The review of economics and statistics, p. 474-481.

[23] Deardorff, A. (1998). Determinants of bilateral trade: does gravity work in a neoclassical world?, in The regionalization of the world economy. University of Chicago Press. p. 7-32.

[24] Anderson, J.E., E. Van Wincoop. (2003). Gravity with gravitas: a solution to the border puzzle. the american economic review, vol. 93(1): p. 170-192.
[25] Helpman, E., M. Melitz, Y. Rubinstein. (2008). Estimating trade flows: Trading partners and trading volumes. The Quarterly Journal of Economics, vol. 123(2): p. 441-487.

[26] Chaney, T. (2008). Distorted gravity: the intensive and extensive margins of international trade. The American Economic Review, vol. 98(4): p. 1707-1721.

[27] Chen, C., et al. (2007). An empirical analysis of Chinese construction firms' entry into Africa. in International Symposium on Advancement of Construction Management and Real Estate.

[28] Kepaptsoglou, K., M.G. Karlaftis, D.(2010), Tsamboulas, The gravity model specification for modeling international trade flows and free trade agreement effects: a 10-year review of empirical studies. The open economics journal,vol. 3(1)

[29] Jian, Z. (2011), Based on gravity trade model and Linder Hypothesis: An empirical application to China-EU trade flows. in Business Management and Electronic Information (BMEI), International Conference on IEEE.

[30] Fontagné, L., M. Pajot, J.-M. Pasteels. (2002), Potentiels de commerce entre économies hétérogènes: un petit mode d'emploi des modèles de gravité. Economie \& prévision, vol(1): p. 115-139.

[31] Gbetnkom, D. , D. Avom.(2005), Intégration par le marché: le cas de l’UEMOA. Région et développement, vol. 22: p. 86-103

[32] Avom, D.(2005), Les déterminants des échanges dans la CEMAC: une évaluation empirique.

[33] Amita, K.(2004), Gate apparatus, on-board unit, setup method of the on-board unit, toll collecting method and judging method of the entrance and exit, Google Patents. 